University of Nebraska - Lincoln

DigitalCommons@University of Nebraska - Lincoln

$2-2021$

\title{
Could energy equilibrium and greenhouse gas emissions in agroecosystems play a key role in crop replacement? A case study in orange and kiwi orchards
}

\author{
Anastasios Mazis \\ University of Nebraska-Lincoln, amazis2@unl.edu \\ Vassilis Litskas \\ Aristotle University of Thessaloniki \\ Dimitrios P. Platis \\ Aristotle University of Thessaloniki \\ Georgios .. Menexes \\ Aristotle University of Thessaloniki \\ Christos D. Anagnostopoulos \\ Aristotle University of Thessaloniki
}

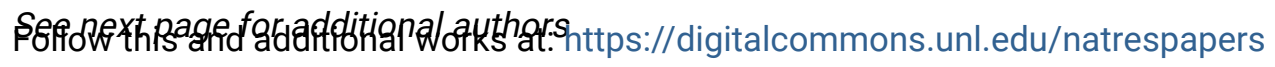

Part of the Natural Resources and Conservation Commons, Natural Resources Management and Policy Commons, and the Other Environmental Sciences Commons

Mazis, Anastasios; Litskas, Vassilis; Platis, Dimitrios P.; Menexes, Georgios ..; Anagnostopoulos, Christos D.; Tsaboula, Aggeliki; Mamolos, Andreas P.; and Kalburtji, Kiriaki L., "Could energy equilibrium and greenhouse gas emissions in agroecosystems play a key role in crop replacement? A case study in orange and kiwi orchards" (2021). Papers in Natural Resources. 1418.

https://digitalcommons.unl.edu/natrespapers/1418

This Article is brought to you for free and open access by the Natural Resources, School of at DigitalCommons@University of Nebraska - Lincoln. It has been accepted for inclusion in Papers in Natural Resources by an authorized administrator of DigitalCommons@University of Nebraska - Lincoln. 


\section{Authors}

Anastasios Mazis, Vassilis Litskas, Dimitrios P. Platis, Georgios .. Menexes, Christos D. Anagnostopoulos, Aggeliki Tsaboula, Andreas P. Mamolos, and Kiriaki L. Kalburtji 


\title{
Could energy equilibrium and greenhouse gas emissions in agroecosystems play a key role in crop replacement? A case study in orange and kiwi orchards
}

\author{
Anastasios Mazis, ${ }^{1,2}$ Vassilis D. Litskas, ${ }^{2,3}$ \\ Dimitrios P. Platis, ${ }^{2}$ Georgios C. Menexes, ${ }^{4}$ \\ Christos D. Anagnostopoulos, ${ }^{2}$ Aggeliki D. Tsaboula, ${ }^{2}$ \\ Andreas P. Mamolos, ${ }^{2}$ and Kiriaki L. Kalburtji ${ }^{2}$ \\ 1 School of Natural Resources, University of Nebraska-Lincoln, 244 North \\ Hardin Hall 3310 Holdrege Street, Lincoln, NE 68583-0982, USA \\ 2 School of Agriculture, Laboratory of Ecology and Environmental Protection, \\ Aristotle University of Thessaloniki, 54124 Thessaloniki, Greece \\ 3 Department of Agricultural Sciences, Biotechnology and Food Science, \\ Cyprus University of Technology, Limassol, Cyprus \\ 4 School of Agriculture, Laboratory of Agronomy, Aristotle University of \\ Thessaloniki, 54124 Thessaloniki, Greece \\ Correspondence - Andreas P. Mamolos, mamolos@agro.auth.gr
}

\begin{abstract}
The development of agriculture is linked to energy resources. Consequently, energy analysis in agroecosystems could be a useful tool for monitoring some measures in the agricultural sector to mitigate greenhouse gas emissions. The objectives of this study were to (a) evaluate differences of energy indices in orange and kiwi orchards, and (b) point out whether inputs, outputs, efficiency, productivity, and
\end{abstract}

Published in Environmental Science and Pollution Research 28 (2021), pp 29421-29431.

doi:10.1007/s11356-021-12774-4

Copyright (C) 2021 Springer-Verlag GmbH Germany, part of Springer Nature. Used by permission.

Submitted 13 July 2020; accepted 29 January 2021; published 8 February 2021. 
carbon footprint can play a key role in crop replacement. Proportional stratified random sampling was used to select 26 orchards (10 oranges, 16 kiwis) from the Prefecture of Arta, western Greece, during 2015 and 2016. Univariate statistical methods were combined with multivariate ones. Nitrogen, $\mathrm{Mg}$, Zn, herbicides, insecticides, fungicides, renewable energy inputs, fruit production, total outputs, and energy efficiency and productivity were statistically significantly high in the orange orchards. Phosphorus, Ca, irrigation, machinery, total inputs, intensity, nonrenewable energy consumption, and carbon footprint were statistically significantly high in the kiwi orchards. The most important energy inputs for both fruit crops were fertilizers, fuels, irrigation, machinery, and herbicides. The orange orchards seem to be more friendly to the environment than the kiwi orchards by having low total energy inputs 32,210.3 $\mathrm{MJ} \mathrm{ha}^{-1}$, intensity 1.4, consumption of non-renewable energy $0.7 \mathrm{MJ} \mathrm{kg}^{-1}$ and $\mathrm{CO}_{2}$ equivalent/fruit production $0.08 \mathrm{~kg} \mathrm{~kg}^{-1}$, and high energy outputs 105,120.0 MJ ha-1 and fruit production 53,648.0 $\mathrm{kg} \mathrm{ha}^{-1}$. The findings of the present study show a relation between climate change and the production of farming systems, which can be a tool for decision makers. The correlation of the abovementioned parameters ensure higher profits and could help in achieving the best possible sustainable management of the agricultural ecosystems.

Keywords: Agricultural practices, Carbon footprint, Energy analysis, Life cycle assessment, Mediterranean agriculture

\section{Introduction}

During the last 40 years, energy inputs of intensified agriculture increased by 137\%, while land use increased less than 10\% (Pellegrini and Fernández 2018). The development of agriculture is linked to energy resources. The increased food production due to the expanded demand led to intensification, a threat to the environment and the energy resources. Less intensive farming methods can minimize the risk of environmental effects (Tilman et al. 2002; Dantsis et al. 2010). Energy efficiency can prevent negative environmental issues and maintain energy resources. Agricultural practices that demand greater quantities of inputs (fuels, fertilizers, irrigation, electricity, insecticides, fungicides, herbicides, and machinery) are held responsible for the rise in energy usage and the accompanied elevated emissions of greenhouse gases (Kavargiris et al. 2009; Michos et al. 2012, 2018). Therefore, an increase in efficiency of the production systems is bounded with the effective use of energy resources and the emissions of greenhouse gases (Kaltsas et al. 2007; Taxidis et al. 2015; Michos et al. 2018). Energy balance determination could provide comprehensive 
information on the environmental impacts of different crop production technologies and management practices, such as greenhouse gas emissions (Lazaroiu et al. 2018). It could help adapt agricultural production and support the most efficient management of the different production coefficients (Elhag and Boteva 2019; Navaro Miro et al. 2019). Energy analysis is affected by the energy inputs and factors such as the location and the production period (Hülsbergen et al. 2001). Consequently, an energy analysis could offer input reduction, which is an environmental policy, while giving a boost to productivity (Michos et al. 2017; Unakitan and Aydin 2018).

Emissions of greenhouse gases are interlinked to energy inputs. The greenhouse gases (mainly $\mathrm{CO}_{2}, \mathrm{CH}_{4}$, and $\mathrm{N}_{2} \mathrm{O}$ ) have a negative impact on the climate. According to IPCC (2014), the agricultural sector accounts for $22 \%$ of the greenhouse gases, while cultivation practices account for $20 \%$ of the $\mathrm{CO}_{2}$ yearly global emissions. The Paris Agreement for the climate demands a drastic reduction of energy inputs (e.g., fuels and fertilizers) and applied farming practices (Bryngelsson et al. 2016). Global and European agricultural policies encompass methods that aim to reduce fossil fuel use, while simultaneously maintain agricultural outputs (Alluvione et al. 2011). New methods and techniques are required to low greenhouse gas emissions down to $80-95 \%$ by 2050 (Adewale et al. 2018; Huang et al. 2019).

In Europe, orange (Citrus sinensis (L.) Osbeck.) and kiwi (Actinidia deliciosa L.) represent $8.4 \%$ and $23.3 \%$ of the global production, respectively (FAO 2017). In Greece, the orange and kiwi output per year is 0.96 and $0.27 \mathrm{Mt}$, respectively, and coincides with an orchard area of $29.6 \times 10^{3}$ (orange) and $9.2 \times 10^{3}$ (kiwi) ha (FAO 2017).

Greece is a Mediterranean region and it is expected that climate change will negatively affect crop production (IPCC 2014). The Mediterranean area is mainly considered an "environmental hotspot" (EspadasAldana et al. 2019). Therefore, it is important to enhance less intensive cultivations and farming practices to improve energy efficiency and reduce greenhouse gas emissions (Alonso and Guzmán 2010). Energy indicators and carbon footprint is a useful tool to achieve the Paris Convention climate targets and to decide the most environmental-friendly crop replacement. Policymakers and farmers can use the life cycle assessment (LCA) method to determine energy indices and greenhouse gas emissions (Taxidis et al. 2015; Michos et al. 2018). 
Climatic changes affect the life cycle of crops and their production cost (Lichtfouse 2011). In Greece, local mid-early orange varieties cultivated at Prefectures Arta and Chania dominated the national orange production in the past. They were later replaced by imported varieties "Navel" and "Valencia" with high fruit production (Minagric 2007). In the Prefecture of Arta, the imported orange varieties had not only high fruit production but high energy inputs as well, leading to high production cost. A result of this was the farmers' willingness to continue with orange cultivation. The rising sell price of kiwi fruit, which can be produced in the region, has led many farmers to abandon oranges and turn to kiwi cultivation. These alterations should take into account the effects on the environment and ensure not only higher profits but the best possible sustainable management of the agricultural ecosystem as well. According to Nabavi-Pelesaraei et al. (2014a, b), the most critical inputs effecting Tangerine production are fertilizers, pesticides, and diesel fuel. Diesel fuel and nitrogen fertilizer are some of the most sensitive inputs for kiwifruit yield and greenhouse gas emissions (Nabavi-Pelesaraei et al. 2016). Mostahari-Rad et al. (2019, 2021) stated that citrus production had lower gas emissions than hazelnut and kiwi. New practices should be adopted to reduce nitrogen fertilizer consumption, utilizing more non-renewable energy and reduce fuel consumption to enhance climate change mitigation and adaptation in agricultural production (Nabavi-Pelesaraei and Amid 2014; Nabavi-Pelesaraei et al. 2016; Michos et al. 2018, Kaab et al. 2019; Ghasemi-Mobtaker et al. 2020).

Given the importance of monitoring sustainable agricultural production (Bracco et al. 2019), it is essential to create and apply indicators to assess and evaluate sustainable agricultural production performance. According to the EC (2020), an environmental impact assessment should include the energy use and the greenhouse gas emissions during agricultural production. In addition, European Union's goals are to reduce the environmental and climate footprint of the EU food system and enhance sustainable food production (EC 2020). The objectives of this study were to (a) evaluate differences of energy indices in kiwi and orange orchards, and (b) point out whether energy inputs, outputs, efficiency, productivity, and carbon footprint can play a key role in crop replacement. 


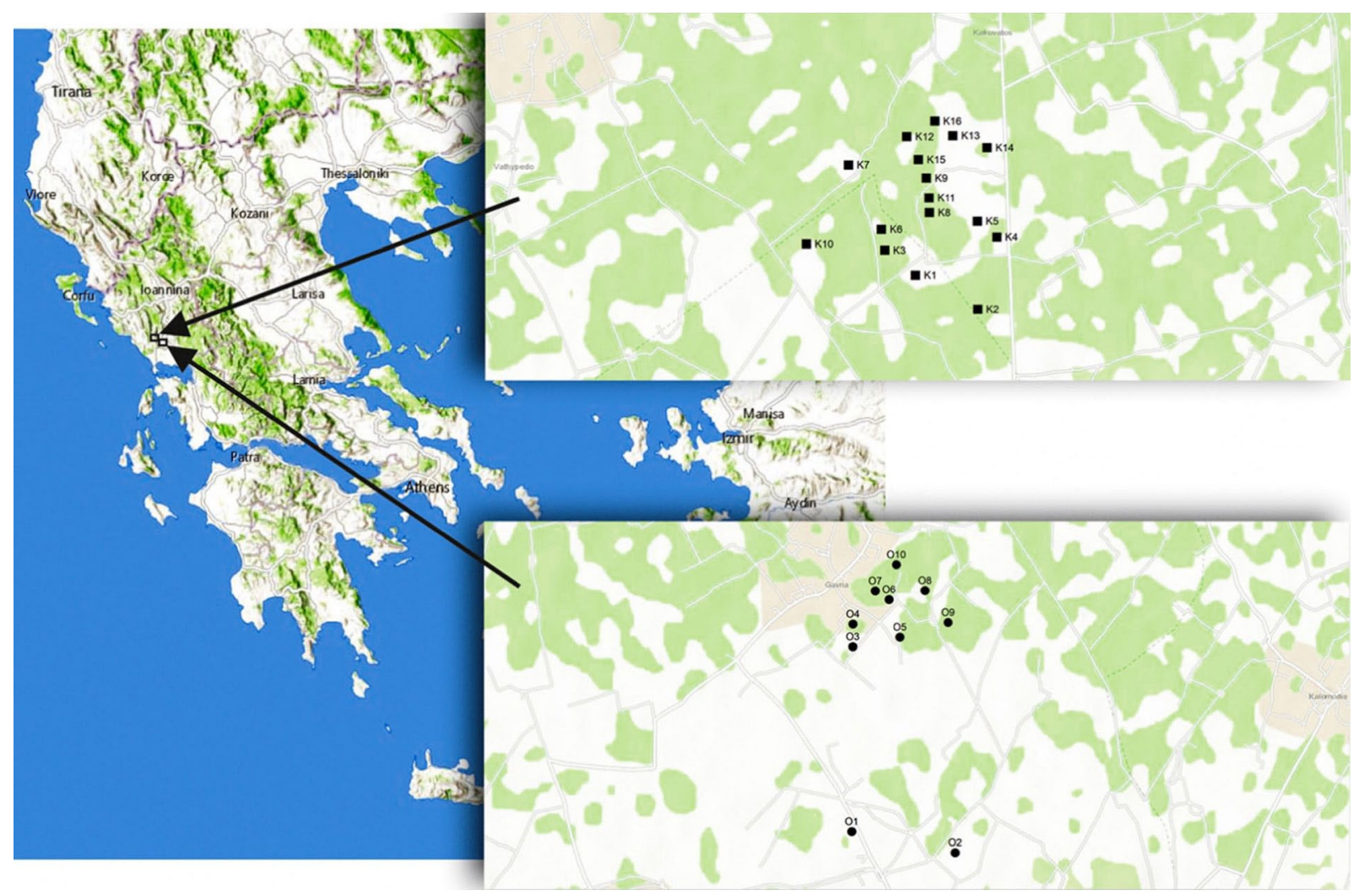

Figure 1 Map of Greece with the selected orange (O) and kiwi (K) orchards in Arta Prefecture

\section{Materials and methods}

\section{Orchards and site information}

During the years 2015 and 2016, 10 orange and 16 kiwi orchards were chosen in Arta Prefecture, western Greece. The studied orange orchards with a total of 19.0 ha out of 204.6 ha of the study area (9.3\%) and the kiwi orchards with a total of 28.8 ha out of 233.5 ha of the study area (12.3\%) were located at the southern part of the Prefecture, near Amvrakikos Gulf. Proportional stratified random sampling was used to select the studied orchards (Figure 1). The two fruit crops (orange and kiwi) were considered as the strata of the sample scheme. The studied orchards were sampled from the local cooperative directory (catalogue) taking into account that about $10 \%$ of the total area of the two fruit crops should be represented into the sample (Michos 
et al. 2017), as described above. Orange orchards had an average size of 1.9 ha and an average age of about 26 years. Kiwi orchards had an average size of 1.8 ha and an age of about 11 years. The studied fruit crops were at their highest production. The altitude of the orange orchards was from 3 to $10 \mathrm{~m}$ and the variety was cv. "Navel." The kiwi orchards altitude was from 4 to $30 \mathrm{~m}$ and the variety was cv. "Hayward." There were $250-370$ trees per ha in the orange orchards and 364-667 vines per ha in the kiwi ones. The owners of these orchards were occupied with their cultivation for more than 15 years. The mean annual precipitation, temperature, and relative humidity (mean \pm SD; $n=15$ years) were $118 \pm 65 \mathrm{~mm}, 19 \pm 5{ }^{\circ} \mathrm{C}$, and $67 \pm 7 \%$, respectively, in the study area (Greek National Meteorological Service).

\section{Life cycle assessment}

Several research papers have been carried out either applying environmental impact assessment methods for the life cycle of agricultural production (Michos et al. 2018; Espadas-Aldana et al. 2019; Litskas et al. 2019; Gkisakis et al. 2020), or categorizing and analyzing assessment methods (Schader et al., 2014). In the present study, an adjusted to agriculture life cycle assessment (LCA) method (Figure 2), involving five stages, was used to determine energy inputs, outputs, and emissions of greenhouse gases (ISO 2006a, b; Finnveden et al. 2009; Zafiriou et al. 2012; Taxidis et al. 2015; Adewale et al. 2016; Litskas et al. 2017, 2019; Michos et al. 2018; Platis et al. 2019).

\section{Energy content}

Table 1 presents the management practices of the orchards during 2015 and 2016. The farmers' work-plan, each activity's duration, the used machines and laborers, the irrigation method, and the amount of the fuels, pesticides, and fertilizers applied were used to estimate the energy inputs. This energy includes the used material, the fuel consumption, and each operation's duration. The embodied energy of the machinery was estimated using the related coefficient indices (Table 2). Most of the machinery used in the studied farms were more than 20 years old. For this reason, the coefficients have been adapted to reflect the status of the machinery structure, materials, use, repairs, cost of 


\section{Goal and scope definition}

- Calculations of energy used in fruit production.

- Determination of fruit crops with low energy inputs.

\section{Inventory analysis}

- Calculation of energy inputs and outputs of fruit production.

\section{Impact assessment}

- Determination of fruit crop management on yields.

\section{Interpetation}

- Evaluation and discussion of results.

\section{Applications}

- Planning replacement of crops.

- Minimizing energy inputs.

- Improving environmental aspects.

Figure 2 A life cycle assessment (LCA; adjusted) with five stages

maintenance practices, and working conditions. The embodied energy of the machinery structure materials derives from the energy for manufacture (86.40 $\mathrm{MJ} \mathrm{kg}^{-1}$ of mass; Pimentel et al. 1973), the energy for repairs and maintenance ( 0.55 times the manufacture energy; Fluck $1985,1992)$, and the energy for transportation (8.80 MJ kg-1; Bridges and Smith 1979). The total embodied energy for each machinery used for the first time is the product of $142.7 \mathrm{MJ} \mathrm{kg}^{-1}$ [86.40 $\mathrm{MJ} \mathrm{kg}^{-1}$ of mass $+\left(0.55 \times 86.40 \mathrm{MJ} \mathrm{kg}^{-1}\right.$ of mass $\left.)+8.80 \mathrm{MJ} \mathrm{kg}^{-1}\right]$ times the weight machinery. The duration of the machinery life is from 2,000 to 15,000 $\mathrm{h}$. An amount of energy is lost per hour of the machinery total life. This amount equals to the ratio of the total embodied energy divided by its total life. The loss of the initial embodied energy is affected by the working hours of the machinery. The required energy for each operation is the sum of the embodied energy and the energy of fuel and human labor (Table 2). Total energy inputs include renewable energy (animal manure, human labor) and non-renewable inputs (chemical fertilizers, pesticides, and fuels). 
Table 1 Farming practices for the selected orange and kiwi orchards

\begin{tabular}{|c|c|c|}
\hline $\begin{array}{l}\text { Agricultural } \\
\text { practices }\end{array}$ & Orange & Kiwi \\
\hline Fertilizer application & $\begin{array}{l}\text { Patentkali }\left(30 \% \mathrm{~K}_{2} \mathrm{O}, 10 \%\right. \\
\mathrm{MgO}_{1} 42.5 \% \mathrm{SO}_{3} \mathrm{Mg} \\
\left.\mathrm{ha}^{-1}, 3 \pm 1 \mathrm{Mg} \mathrm{ha}^{-1}\right) \text { and } \\
\text { fertilizers with different } \\
\text { composition }(12 \% \mathrm{~N}, 8 \% \\
\mathrm{P}_{2} \mathrm{O}_{5}, 16 \% \mathrm{~K}_{2} \mathrm{O} ; 1 \pm \\
0.2 \mathrm{Mg} \mathrm{ha}^{-1} \text { or } 11 \% \mathrm{~N}, \\
15 \% \mathrm{P}_{2} \mathrm{O}_{5}, 15 \% \mathrm{~K}_{2} \mathrm{O} ; 0.9 \\
\pm 0.1 \mathrm{Mg} \mathrm{ha}^{-1} \text { or } 20 \% \mathrm{~N}, \\
20 \% \mathrm{P}_{2} \mathrm{O}_{5}, 20 \% \mathrm{~K}_{2} \mathrm{O} ; 1.2 \\
\left. \pm 0.2 \mathrm{Mg} \mathrm{ha}^{-1}\right) \text {. The } \\
\text { fertilizers are applied } 2 \text { or } \\
4 \text { times year }{ }^{-1} \text {. }\end{array}$ & 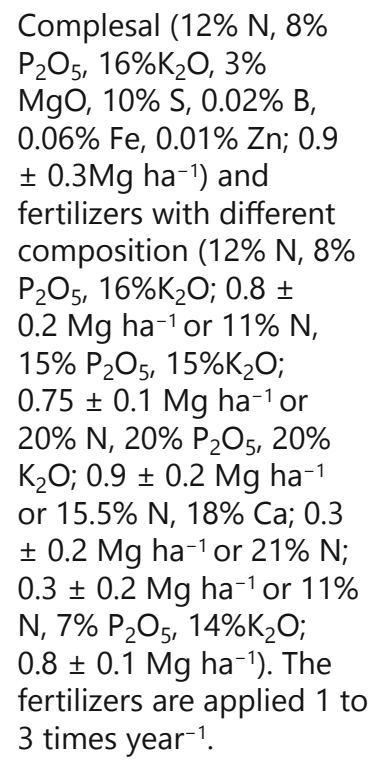 \\
\hline Weed control & $\begin{array}{l}\text { Farmers are cutting weeds } \\
\left(3-5 \text { times year }{ }^{-1}\right) \text { by } \\
\text { using machinery (lawn } \\
\text { mower) or by hand. }\end{array}$ & $\begin{array}{l}\text { Farmers are cutting weeds } \\
(4-6 \text { times year-1) by } \\
\text { using machinery (lawn } \\
\text { mower). }\end{array}$ \\
\hline Fungicides & $\begin{array}{l}\text { Farmers apply ( } 2 \text { times } \\
\text { year-1) quantities of } \\
\text { copper hydroxide, which } \\
\text { range from } 0 \text { to } 0.8 \mathrm{~kg} \\
\text { ha }^{-1} \text { totally. }\end{array}$ & $\begin{array}{l}\text { Farmers apply ( } 2-4 \text { times } \\
\text { year }^{-1} \text { ) quantities of } \\
\text { Bordeaux mixture, } \\
\text { copper hydroxide, and } \\
\text { Mancozeb, which range } \\
\text { from } 0.3 \text { to } 5.8 \mathrm{~kg} \mathrm{ha}^{-1} \\
\text { totally. }\end{array}$ \\
\hline Insecticides & $\begin{array}{l}\text { Farmers apply ( } 1-2 \text { times } \\
\text { year }{ }^{-1} \text { ) quantities of } \\
\text { paraffinic mineral oil, } \\
\text { pyrethrins, which range } \\
\text { from } 0.8 \text { to } 3.0 \mathrm{~kg} \mathrm{ha}^{-1} \\
\text { totally. }\end{array}$ & $\begin{array}{l}\text { Farmers apply ( } 1-2 \text { times } \\
\text { year }-1) \text { quantities of } \\
\text { imidacloprid and } \\
\text { pyriproxyfon, which } \\
\text { range from } 1.5 \text { to } 1.8 \mathrm{~kg} \\
\text { ha }^{-1} \text { totally. }\end{array}$ \\
\hline Pruning & $\begin{array}{l}\text { One or } 2 \text { times year-1 } \\
\text { (November to December, } \\
\text { June to August) with } \\
\text { aero-scissors }\end{array}$ & $\begin{array}{l}\text { Two times year-1 } \\
\text { (November to December, } \\
\text { June to August) with } \\
\text { aero-scissors }\end{array}$ \\
\hline Irrigation & $\begin{array}{l}\text { From April to June } 7-17 \\
\text { times with sprinkler } \\
\text { heads functioning }\end{array}$ & Same practices \\
\hline Fruit thinning & From April to June by hand & Same practices \\
\hline Harvesting & $\begin{array}{l}\text { During the October and } \\
\text { November by hand }\end{array}$ & Same practices \\
\hline
\end{tabular}


Table 2 Energy content of inputs

\begin{tabular}{|c|c|c|c|c|c|}
\hline Item & Unit & $\begin{array}{l}\text { Content } \\
\text { energy } \\
\text { (MJ/unit) }\end{array}$ & $\begin{array}{l}\text { Mass } \\
(\mathrm{kg})\end{array}$ & $\begin{array}{l}\text { Life } \\
\text { (h) }\end{array}$ & References \\
\hline \multicolumn{6}{|l|}{ Fertilizer } \\
\hline Nitrogen $(\mathrm{N})$ & $\mathrm{kg}$ & 74.2 & & & Lockeretz (1980); Tsatsarelis (1993) \\
\hline Phosphorus (P) & $\mathrm{kg}$ & 13.7 & & & Lockeretz (1980); Tsatsarelis (1993) \\
\hline Potassium (K) & $\mathrm{kg}$ & 9.7 & & & Lockeretz (1980); Tsatsarelis (1993) \\
\hline Calcium (Ca) & $\mathrm{kg}$ & 8.8 & & & Pimentel (1980) \\
\hline Magnesium (Mg) & $\mathrm{kg}$ & 8.8 & & & Pimentel (1980) \\
\hline Zink (Zn) & $\mathrm{kg}$ & 8.4 & & & Pimentel (1980) \\
\hline Sulfur (S) & $\mathrm{kg}$ & 3.0 & & & Mudahar and Hignett (1987) \\
\hline Cupper (Cu) & $\mathrm{kg}$ & 13.3 & & & Pimentel (1980) \\
\hline Agrobiozol & $\mathrm{kg}$ & 6.5 & & & Kavargiris et al. (2009) \\
\hline Patenkali & $\mathrm{kg}$ & 6.0 & & & Kaltsas et al. (2007) \\
\hline Sheep and goat manure & $\mathrm{kg}$ & 23.5 & & & Makhijani and Poole 1975) \\
\hline Insecticides & $\mathrm{kg}$ & 363.6 & & & Kaltsas et al. (2007) \\
\hline Microbial insecticides & $\mathrm{kg}$ & 290.0 & & & Kaltsas (2005) \\
\hline Paraffin & I & 46.0 & & & Tsatsarelis (2011) \\
\hline Fungicides & $\mathrm{kg}$ & 99.0 & & & Kaltsas et al. (2007) \\
\hline Herbicides & $\mathrm{kg}$ & 418 & & & Kavargiris et al. (2009) \\
\hline Petroleum (diesel)a & I & 47.3 & & & Cervinka (1980) \\
\hline Electric energy & $\mathrm{kWh}$ & 12.1 & & & Jarach (1985) \\
\hline \multicolumn{6}{|l|}{ Machinery } \\
\hline Tractor 48kw & $\mathrm{h}$ & 41.4 & 4350 & 15000 & Tsatsarelis (1992) adapted \\
\hline Pump & $\mathrm{h}$ & 2.4 & 200 & 12000 & Tsatsarelis (1992) adapted \\
\hline Fertilizer distributor & $\mathrm{h}$ & 5.7 & 100 & 2500 & Tsatsarelis and Koundouras (1994) adapted \\
\hline Manure distributor & $\mathrm{h}$ & 14.28 & 100 & 2500 & Tsatsarelis and Koundouras (1994) adapted \\
\hline Branch destroyer & $\mathrm{h}$ & 17.7 & 300 & 2500 & Tsatsarelis and Koundouras (1994) adapted \\
\hline Irrigation system & h.m & 0.092 & -- & 15000 & Tsatsarelis (1992) adapted \\
\hline Field cultivator & h & 17.1 & 300 & 2500 & Tsatsarelis (1991) adapted \\
\hline Rotary tiller & $\mathrm{h}$ & 17.7 & 310 & 2500 & Tsatsarelis and Koundouras (1994) adapted \\
\hline Sprayer & $\mathrm{h}$ & 19.1 & 200 & 1500 & Tsatsarelis and Koundouras (1994) adapted \\
\hline Lawn mower & $\mathrm{h}$ & 1 & 10 & 1500 & Tsatsarelis (1993) adapted \\
\hline Transportation & $\mathrm{h}$ & 48.9 & 1500 & 15000 & Genitsariotis et al. $(1996,2000)$ adapted \\
\hline Platform & $\mathrm{h}$ & 57.1 & 1000 & 15000 & Tsatsarelis (1992) adapted \\
\hline Insect traps & $\mathrm{h}$ & 0.002 & 0.3 & 18000 & Tsatsarelis (1993) adapted \\
\hline Tank $0.5 \mathrm{Mg}$ & $\mathrm{h}$ & 14.3 & & & Kaltsas et al. (2007) adapted \\
\hline Tank $1.0 \mathrm{Mg}$ & $\mathrm{h}$ & 23.8 & & & Kaltsas et al. (2007) adapted \\
\hline Tank $2.0 \mathrm{Mg}$ & $\mathrm{h}$ & 33.3 & & & Kaltsas et al. (2007) adapted \\
\hline Tank $3.0 \mathrm{Mg}$ & $\mathrm{h}$ & 47.6 & & & Kaltsas et al. (2007) adapted \\
\hline Komfler & $\mathrm{h}$ & 16.4 & & & Genitsariotis et al. $(1996,2000)$ adapted \\
\hline Aero-scissors & $\mathrm{h}$ & 0.035 & & & Genitsariotis et al. $(1996,2000)$ adapted \\
\hline Tools (knives etc.) & $\mathrm{h}$ & 0.05 & & & Kaltsas et al. (2007) \\
\hline Labor & $\mathrm{h}$ & 2.2 & & & Pimentel and Pimentel (1996) \\
\hline Orange fruit & $\mathrm{Mg}$ & 1960 & & & Ozkan et al. (2004) \\
\hline Kiwi fruit & $\mathrm{Mg}$ & 2420 & & & Jarach (1985) adapted \\
\hline Shoots & $\mathrm{Mg}$ & 18.4 & & & Pimentel (1980) adapted \\
\hline
\end{tabular}

a. Energy content + energy for production 


\section{Carbon footprint}

The amount of fossil fuel used was determined by the amount of diesel (liters), which was used for the reservoir refilling in order to proceed to various farming activities (e.g. fertilizer, herbicide, insecticide, and fungicide application). The amount and type of fertilizer used in each farming system are shown in Table 1. Carbon dioxide, $\mathrm{CH}_{4}$, and $\mathrm{N}_{2} \mathrm{O}$ emissions were estimated for fertilizer production and fertilizer application in soil and fuels (IPCC 1997, 2006; Küstermann et al. 2008; EMEP/EEA 2009; ISO 2013; Pandey and Agrawal 2014). The emissions of the greenhouse gases for fertilizers and fuels were transformed to $\mathrm{CO}_{2}$ equivalents (Eurostat 2020). Greenhouse gases emitted from fertilizer production and fertilizer (mainly $\mathrm{N}$ ) application in soil and fuels expressed as $\mathrm{CO}_{2}$ equivalent are the main contributors to global warming potential (GWP) in crop production (IPCC 2014). Global warming potential accounts for greenhouse gas capacity to absorb radiation and their residence time in the atmosphere. Total crop carbon footprint is the sum of the individual greenhouse gases emitted during the cultivating period divided by crop yield.

\section{Statistical analyses}

In order to explore the association among the measured energy balance or/and emissions of greenhouse gas variables, the corresponding Spearman's rho rank correlation index has been calculated and assessed. Indices of descriptive statistics (means and percentages \%) have been also calculated. A series of Mann-Whitney (M-W) tests were performed in order to test the differences between orange and kiwi orchards relative to production coefficients and other 23 derived variables (e.g., total energy inputs, outputs, fruit production, efficiency, productivity, intensity, emissions of $\mathrm{CO}_{2}, \mathrm{CH}_{4}, \mathrm{~N}_{2} \mathrm{O}$, and $\mathrm{CO}_{2}$ equivalents). The $P$ values in all M-W tests were computed using the MonteCarlo method (Mehta and Patel 1996) utilizing 10,00o random samples in each run. This methodological approach leads to valid conclusions even in cases where the assumptions of the test are not satisfied. The statistical analysis was accomplished with SPSS ver. 15.0 software enhanced with the module Exact Tests (for Monte-Carlo implementation). The significance level in all hypothesis testing was predetermined at $\mathrm{a}=0.05(P \leq 0.05)$. 


\section{Results}

\section{Energy balance parameters}

Table 3 presents mean values of production coefficients in orange and kiwi orchards. The nutrients' quantity in the fertilizers used was calculated to understand the demands of each crop, the needs for every nutrient, and the production coefficients of them. The production coefficients of $\mathrm{N}, \mathrm{Mg}$, Zn, fungicides, insecticides, and herbicides had statistically significant higher values in orange than in kiwi orchards. The production coefficients of $\mathrm{P}, \mathrm{Ca}$, irrigation, and machinery had statistically significant lower values in orange than in kiwi orchards. The most important production coefficients in orange and kiwi orchards were fertilizers (35.0 and 26.6\%), fuels (34.2 and $25.9 \%$ ), irrigation (11.7 and 25.4\%), machinery (11.0 and 14\%), herbicides (4.0\% and 5.5\%), fungicides (2.2 and 1.4\%), and labor (1.4 and $0.7 \%$ ).

For all orchards $(n=26)$, the Spearman's rank correlation coefficients were statistically significant between: human labor and machinery ( $r h o=0.44, P=0.024$ ), fuel and transportation ( $r h o=0.53, P=$ $0.005)$, irrigation and insecticides ( $r h o=0.83, P<0.001)$, irrigation

Table 3 Mean values (min-max, standard deviation) of production coefficients in orange and kiwi orchards. Means with different exponential letters in the same row are statistically significantly different

\begin{tabular}{|c|c|c|c|}
\hline Production coefficients & Orange $(n=10)$ & Kiwi $(n=16)$ & $P^{1}$ \\
\hline Fertilizers (MJ ha ${ }^{-1}$ ) & $17,604.0^{\mathrm{a}}(14,000-21,380,2,425)$ & $16,845.0^{\mathrm{a}}(15,539-17,850,661)$ & 0.506 \\
\hline $\mathrm{N}\left(\mathrm{MJ} \mathrm{ha}^{-1}\right)$ & $14,729.0^{a}(11,130-18,550,2,565)$ & $12,688.8^{\mathrm{b}}(11,501-13,356,660)$ & 0.049 \\
\hline $\mathrm{P}\left(\mathrm{MJ} \mathrm{ha}^{-1}\right)$ & $651.0^{\mathrm{b}}(548-822,93)$ & $795.0^{\mathrm{a}}(685-959,78)$ & $<0.001$ \\
\hline $\mathrm{K}\left(\mathrm{MJ} \mathrm{ha}^{-1}\right)$ & $1,635.0^{\mathrm{a}}(1,455-1,940,158)$ & $1,170.0^{\mathrm{a}}(1,407-2,134,215)$ & 0.485 \\
\hline $\mathrm{Ca}\left(\mathrm{MJ} \mathrm{ha}^{-1}\right)$ & $62.0^{\mathrm{b}}(0-88,31)$ & $1,230.0^{a}(1,056-1,496,125)$ & $<0.001$ \\
\hline $\mathrm{Mg}\left(\mathrm{MJ} \mathrm{ha} \mathrm{a}^{-1}\right)$ & $259.6^{a}(176-308,43.8)$ & $58.9^{\mathrm{b}}(0-176,44.5)$ & $<0.001$ \\
\hline $\mathrm{S}\left(\mathrm{MJ} \mathrm{ha} \mathrm{h}^{-1}\right)$ & $67.5^{\mathrm{a}}(60-90,10.6)$ & $71.6^{\mathrm{a}}(60-90,10.0)$ & 0.293 \\
\hline Zn $\left(\mathrm{MJ} \mathrm{ha}^{-1}\right)$ & $201.6^{a}(168-252,38.6)$ & $127.6^{\mathrm{b}}(84-168,33.2)$ & $<0.001$ \\
\hline Fungicides (MJ ha-1) & $1,107.4^{\mathrm{a}}(927-1,361,148)$ & $854.6^{\mathrm{b}}(645-1,092,155)$ & $<0.001$ \\
\hline Insecticides (MJ ha-1) & $157.6^{a}(91-242,93)$ & $0.0^{b}(0-0,0)$ & $<0.001$ \\
\hline Herbicides (MJ ha-1) & $2,007.4^{a}(1,463-2,717,419)$ & $3,477.3^{b}(2,943-4,055,271)$ & $<0.001$ \\
\hline Diesel (MJ ha-1) & $17,185.4^{a}(15,635-21,570,2,078)$ & $16,377.9^{a}(16,217-16,555,2,425)$ & 0.725 \\
\hline Labor (MJ ha-1) & $521.9^{a}(292-925,117)$ & $442.1^{\mathrm{a}}(262-741,142)$ & 0.505 \\
\hline Irrigation (MJ ha-1) & $5,863.4^{\mathrm{b}}(2,961-10,614,2,258)$ & $16,085.0^{a}(8,658-25,725,5,449)$ & $<0.001$ \\
\hline Machinery (MJ ha-1) & $5,539.6^{\mathrm{b}}(2,001-9,695,93)$ & 8,833.9a $(3,662-15,899,4,265)$ & $<0.001$ \\
\hline Transportation (MJ ha-1) & $281.6^{a}(107-608,148)$ & $360.0^{\mathrm{a}}(108-881,216)$ & 0.313 \\
\hline
\end{tabular}

1. $P$ value from Mann-Whitney test 
and fungicides ( $r h o=0.55, P=0.004$ ), irrigation and herbicides ( $r h o$ $=0.70, P<0.001$ ), fruit production and insecticides ( $r h o=0.65, P<$ 0.001), fruit production and fungicides ( $r h o=0.65, P<0.001$ ), fruit production and herbicides ( $r h o=0.51, P=0.008$ ), and fruit production and renewable inputs ( $r h o=-0.50, P=0.009$ ).

Comparisons of the orange and kiwi orchards, relative to their mean values of 23 derived variables, are presented in Table 4. Orange orchards showed the highest renewable inputs, fruit production, total energy outputs, energy efficiency, and productivity (Table 4). Total energy inputs, intensity, and non-renewable energy consumption were the highest in kiwi orchards (Table 4).

Table 4 Comparison between orange and kiwi orchards relative to themean values (min-max, standard deviation) of 23 derived variables. Means with different exponential letters in the same row are statistically significant different

\begin{tabular}{|c|c|c|c|}
\hline Variables & Orange $(n=10)$ & $\operatorname{Kiwi}(n=16)$ & $P^{1}$ \\
\hline Renewable energy inputs (MJ ha-1) & $14,729.0^{a}(11,130-18,550,2,565)$ & $4,927.7^{b}(3,536-10,920,5,557)$ & $<0.001$ \\
\hline Non-renewable energy inputs (MJ ha-1) & $38,061.9^{a}(33,278-44,897,4,053)$ & $37,554.6^{a}(35,804-38,729,831)$ & 0.780 \\
\hline Total energy inputs (MJ ha-1) & $32,210.3^{\mathrm{b}}(25,460-40,259,5,179)$ & $42,482.3^{a}(35,192-52,260,5,451)$ & $<0.001$ \\
\hline Fruit production (kg ha-1) & $53,648.0^{a}(22,455-97,987,910)$ & $22,376.0^{\mathrm{b}}(10,909-39,669,7,341)$ & $<0.001$ \\
\hline Total energy outputs (MJ ha-1) & $105,120.0^{\mathrm{a}}(44,000-192,000,858)$ & $54,150.0^{\mathrm{b}}(26,400-96,000,17,766)$ & $<0.001$ \\
\hline Energy efficiency ${ }^{2}$ & $3.3^{\mathrm{a}}(2-5.2,1)$ & $1.3^{b}(0.4-2,0.5)$ & $<0.001$ \\
\hline Fertilizers energy efficiency 3 & $6.1^{\mathrm{a}}(1-12,3)$ & $3.2^{\mathrm{b}}(2-5,1)$ & $<0.001$ \\
\hline Fungicides energy efficiency ${ }^{3}$ & $97.5^{\mathrm{a}}(18-175,42)$ & $65.3^{\mathrm{b}}(24-102,23)$ & $<0.013$ \\
\hline Insecticides energy efficiency ${ }^{3}$ & $716.2^{\mathrm{a}}(138-1,219,349)$ & $0.0^{\mathrm{b}}(0-0,0)$ & $<0.001$ \\
\hline Herbicides energy efficiency ${ }^{3}$ & $53.1^{\mathrm{a}}(13-81,21)$ & $15.7^{b}(8-27,5)$ & $<0.001$ \\
\hline Labor energy efficiency ${ }^{3}$ & $250.6^{\mathrm{a}}(27-658,170)$ & $138.2^{\mathrm{b}}(46-274,67)$ & 0.023 \\
\hline Machinery energy efficiency ${ }^{3}$ & $24.5^{\mathrm{a}}(3-54,16)$ & $8.1^{\mathrm{b}}(2-18,5)$ & $<0.001$ \\
\hline Irrigation energy efficiency ${ }^{3}$ & $20.9^{a}(2-42,11)$ & $3.6^{\mathrm{b}}(2-6,1)$ & $<0.001$ \\
\hline Fuel energy efficiency ${ }^{3}$ & $6.2^{\mathrm{a}}(2-12,3)$ & $3.3^{\mathrm{b}}(2-6,1)$ & $<0.001$ \\
\hline Transportation efficiency ${ }^{3}$ & $430.1^{\mathrm{a}}(178-1,044,255)$ & $212.0^{b}(30-447,135)$ & 0.007 \\
\hline Energy productivity ${ }^{4}\left(\mathrm{~kg} \mathrm{MJ}^{-1}\right)$ & $0.7^{\mathrm{a}}(0.1-1.5,0.5)$ & $0.5^{b}(0.1-0.8,0.4)$ & $<0.001$ \\
\hline Intensity $\left(\mathrm{MJ} \mathrm{kg}{ }^{-1}\right)$ & $1.4^{\mathrm{b}}(0.5-2.1,1.2)$ & $2.0^{\mathrm{a}}(0.8-3.8,1.6)$ & $<0.001$ \\
\hline Renewable energy consumption ${ }^{6}\left(\mathrm{MJ} \mathrm{kg}^{-1}\right)$ & $0.3^{\mathrm{a}}(0-0.4,0.2)$ & $0.2^{\mathrm{a}}(0-0.5,0.4)$ & $<0.881$ \\
\hline Non-renewable energy consumption ${ }^{6}\left(\mathrm{MJ} \mathrm{kg}^{-1}\right)$ & $0.7^{b}(0.1-1,0.5)$ & $1.7^{\mathrm{a}}(0.5-2.2,1.1)$ & $<0.001$ \\
\hline $\mathrm{CO}_{2}\left(\mathrm{Mg} \mathrm{ha}^{-1}\right)$ & $1.41^{\mathrm{a}}(1-1.6,0.2)$ & $1.49^{a}(1.2-1.9,0.01)$ & 0.725 \\
\hline $\mathrm{CH}_{4}\left(\mathrm{~kg} \mathrm{ha}^{-1}\right)$ & $0.21^{\mathrm{a}}(0.16-0.27,0.0)$ & $0.24^{\mathrm{a}}(0.17-0.22,0.02)$ & 0.755 \\
\hline $\mathrm{N}_{2} \mathrm{O}\left(\mathrm{kg} \mathrm{ha}^{-1}\right)$ & $0.20^{\mathrm{a}}(0.1-0.25,0.0)$ & $0.26^{\mathrm{a}}(0.09-0.35,0.13)$ & 0.727 \\
\hline $\mathrm{CO}_{2}$ equivalents per fruit production $\left(\mathrm{kg} \mathrm{kg}^{-1}\right)$ & $0.13^{\mathrm{b}}(0.1-0.2,0.0)$ & $0.25^{\mathrm{a}}(0.16-0.37,0.0)$ & $<0.001$ \\
\hline
\end{tabular}

1. $\mathrm{M}-\mathrm{W}(P)=P$ value from Mann-Whitney test

2. Energy outputs per total energy inputs

3. Energy outputs per energy inputs for each factor

4. The ratio of fruit produced to the energy inputs in production

5. The reciprocal of the energy productivity index

6. Renewable or non-renewable energy inputs/fruit production 


\section{Emissions of greenhouse gases}

Emissions of greenhouse gases in orange and kiwi orchards were evaluated for each cultivation practice, fertilizers, soils, and fuels. Emission indices $\left(\mathrm{CO}_{2}, \mathrm{CH}_{4}, \mathrm{~N}_{2} \mathrm{O}\right)$ and $\mathrm{CO}_{2}$ equivalents/fruit production are shown in Table 4 . The $\mathrm{CO}_{2}$ equivalents/fruit production had statistically significant higher values in kiwi than in orange orchards (Table 4).

For all orchards $(n=26)$, the Spearman's rank correlation coefficients were statistically significant between: $\mathrm{CO}_{2}$ and $\mathrm{N}$ ( $r h o=0.61$, $P=0.001$ ), $\mathrm{CO}_{2}$ and fertilizers ( $r h o=0.68, P<0.001$ ), $\mathrm{CO}_{2}$ and nonrenewable energy inputs ( $r h o=0.74, P<0.001$ ), $\mathrm{CO}_{2}$ and transportation ( $r h o=0.53, P=0.005), \mathrm{CH}_{4}$ and $\mathrm{N}$ ( $r h o=0.62, P=0.001$ ), $\mathrm{CH}_{4}$ and fertilizers ( $r h o=0.69, P<0.001), \mathrm{CH}_{4}$ and non-renewable energy inputs ( $r h o=0.73, P<0.001$ ), $\mathrm{CH}_{4}$ and transportation ( $r h o=0.55$, $P=0.005), \mathrm{N}_{2} \mathrm{O}$ and $\mathrm{N}$ ( $\left.r h o=0.61, P=0.001\right), \mathrm{N}_{2} \mathrm{O}$ and fertilizers (rho $=0.69, P<0.001$ ), $\mathrm{N}_{2} \mathrm{O}$ and non-renewable energy inputs (rho = 0.74, $P<0.001$ ), $\mathrm{N}_{2} \mathrm{O}$ and transportation ( $r h o=0.52, P<0.005$ ), $\mathrm{CO}_{2}$ equivalents/fruit production and $\mathrm{N}$ ( $\left.r h o=0.71, P<0.001\right), \mathrm{CO}_{2}$ equivalents/fruit production and fertilizers ( $r h o=0.78, P<0.001$ ), $\mathrm{CO}_{2}$ equivalents/fruit production and non-renewable energy inputs (rho $=0.84, P<0.001$ ), $\mathrm{CO}_{2}$ equivalents/fruit production and transportation ( $r h o=0.62, P=0.001)$.

\section{Discussion}

\section{Energy balance parameters}

For both fruit crops, the ordering pattern for the coefficients of production was fertilizers, fuels, irrigation, machinery, products for plant protection, and human labor. Fertilizer use was the highest of the inputs for both of them. Any reduction of the amounts of applied fertilizers could diminish the total energy inputs. Lower irrigation could be achieved by reducing the amount of water used and using alternative irrigation methods. The machinery modification in order to do more than one cultivation practices simultaneously (e.g., fertilizer application on the lines and weed control between the lines) could control 
machinery and fuel inputs. The increase of human labor could also help. The latter could contribute in the reduction of unemployment. For both studied crops, the first three most important coefficients were fertilizers, fuels, and irrigation. Michos et al. (2017) reported that irrigation and fuels were the major inputs for kiwi cultivation. The means of the most important energy inputs in descending order for other crops were electric energy (43\%), fuels (41.5\%), fertilization (32\%), and machinery (23\%) (Baldini et al. 1982; Ozkan et al. 2004; Strapatsa et al. 2006; Kaltsas et al. 2007; Litskas et al. 2011, 2013; Kehagias et al. 2015; Michos et al. 2017, 2018).

Fruit production (output) was higher in orange orchards compared to kiwi orchards. Site-specific factors (local farming practices) affected the performance of different pear production agronomic systems (Liu et al. 2010). Local farming practices, being less intensive, could have a major contribution to maintain an equilibrium between climate change and the production of farming systems. This could ensure the sustainable management of the agricultural ecosystems and lead to better profits for the farmers. Furthermore, in order to understand the role of the abovementioned agro-environmental indices on fruit production, more factors may be included as variables, such as farmers' specific characteristics (e.g., farmers' age, level of training, experience) (Raheli et al. 2017). Renewable energy inputs and total energy outputs followed the same pattern as energy efficiency, in orange orchards. By an energy standpoint, the orange orchards are more efficient than the kiwi ones and the orange farmers are more experienced and apply better management practices.

\section{Emissions of greenhouse gases}

Fertilizers (mainly N), fuels, and soil cultivation are mainly responsible for global warming potential related to crop production (IPCC 2014). The largest contributors for emissions of greenhouse gases were fertilizers, fuels and machinery in orange orchards (NabaviPelesaraei et al. 2014a, b), mechanization and fertilizers in apple orchards (Milà i Canals et al. 2006), fertilizers in pear orchards (Liu et al. 2010), and fuels in vineyards (Villanueva-Rey et al. 2014). In this study, the largest contributors were fertilizers (mainly N) and fuels. Carbon footprint values were lower in orange orchards than in kiwi 
orchards due to better management of farming practices. The negative value of Spearman's rank correlation coefficient between renewable inputs and fruit production ( $r h o=-0.50, P<0.01$ ) indicates that low renewable inputs combined with high non-renewable inputs are related with high fruit production and carbon footprint. Renewable and non-renewable inputs in wheat farms were related to carbon footprint (Khoshnevisan et al. 2013). Farmers by applying best management practices and using renewable inputs in their farms could diminish carbon footprint. Farming systems with efficient management practices, less fuel consumption, and effective use of renewable energy resources could be green systems with a low carbon footprint.

\section{Conclusions}

Kiwi orchards were more demanding in energy use than orange orchards since they had higher total inputs. Orange orchard outputs were almost double of those in kiwi orchards. This combined with the lower energy inputs indicates a cultivation more effective and friendly to the environment. The renewable inputs used in orange orchards were higher than in kiwi orchards. The lower fruit production along with the used amounts of non-renewable energy inputs for kiwi orchards resulted in slightly more greenhouse gas emissions compared to orange orchards. The climatic conditions and the soil of the studied region are suitable for the cultivation of kiwi vines. This combined with the rising price of kiwifruit led many farmers to "abandon" the orange orchards and turn to kiwi cultivation. The results of the present research showed that in short term, kiwi vines can be a more profitable cultivation than orange orchards, but in long term, the latter by having lower energy inputs and carbon footprint are more friendly to the environment. The orange orchards could create a more sustainable agricultural ecosystem than kiwi orchards. So, agricultural policy decision makers and farmers thinking the replacement of a crop with one which is "more profitable" should take under consideration the parameters related to the environment cost, as well. Sometimes, a "more profitable" crop becomes more expensive than the replaced, through high energy inputs and carbon footprint. 
Acknowledgments The authors are deeply thankful to the agronomists of the Office of Agricultural Development of the Prefecture of Arta and farmers participated in the present study.

Authors' contributions The authors contributed according to their research specialty: AM: The thesis' author; APM, GCM, KLK: Three supervisors of the thesis; VDL, DPP, CDA, ADT: Technical support, team members, editing. All authors read and approved the final manuscript.

Declarations The authors have no competing interests.

\section{References}

Adewale C, Reganold JP, Higgins S, Evans RD, Carpenter-Boggs L (2018)

Improving carbon footprinting of agricultural systems: boundaries, tiers, and organic farming. Environ Impact Asses 71: 41-48. https://doi.org/10.1016/j. eiar.2018.04.004

Adewale C, Stewart-Higgins S, Granatstein D, Stöckle OC, Carlson BR (2016) Identifying hotspots in the carbon footprint of a small scale organic vegetable farm. Agric Syst 149:112-121. https://doi.org/10.1016/j.agsy.2016.09.004

Alluvione F, Moretti B, Sacco D, Grignani C (2011) EUE (energy use efficiency) of cropping systems for a sustainable agriculture. Energy 36:4468-4481. https:// doi.org/10.1016/j.energy.2011.03.075

Alonso AM, Guzmán GJ (2010) Comparison of the efficiency and use of energy in organic and conventional farming in Spanish agricultural systems. J Sustain Agr 34(3):312-338. https://doi.org/10.1080/10440041003613362

Baldini E, Alberghina O, Bargioni G et al (1982) Analisi energetiche di alcune colture arboree da frutto 3 4. Melo Riv Ing Agrar 13:119-130

Bracco S, Tani A, Çalıcıoğlu Ö, Gomez San Juan M, Bogdanski A (2019) Indicators to monitor and evaluate the sustainability of bioeconomy. Overview and a Proposed Way Forward. FAO, Rome. http://www.fao.org/3/ca6048en/ ca6048en.pdf Accessed 20 January 2021.

Bridges TC, Smith EM (1979) A method for determining the total energy input for agricultural practices. T ASAE 22:781-784

Bryngelsson D, Wirsenius S, Hedenus F, Sonesson U (2016) How can the EU climate targets be met? A combined analysis of technological and demandside changes in food and agriculture. Food Policy 59: 152-164. https://doi. org/10.1016/j.foodpol.2015.12.012

Cervinka V (1980) Fuel and energy efficiency. In: Pimentel D (ed) Handbook of energy utilization in agriculture. CRC Press, Boca Raton, FL, pp 15-21

Dantsis T, Douma C, Giourga C, Loumou A, Polychronaki EA (2010) A methodological approach to assess and compare the sustainability level of agricultural plant production systems. Ecol Indicat 10:256- 263. https://doi. org/10.1016/j.ecolind.2009.05.007 
Elhag M, Boteva S (2019) Conceptual assessment of energy input-output analysis and data envelopment analysis of greenhouse crops in Crete Island, Greece. Environ. Sci Pollut Res 26:35377-35386. https://doi.org/10.1007/ s11356-019-05544-W

EMEP/EEA (2009) Air pollutant emission inventory guidebook, Technical report No 9. Copenhagen: European Environment Agency.

Espadas-Aldana G, Vialle C, Belaud JP, Vaca-Garcia C, Sablayrolles C (2019) Analysis and trends for life cycle assessment of olive oil production. Sustain Prod Consumption 19:216-230. https://doi.org/10.1016/j.spc.2019.04.003

European Commission (2020) A farm to fork strategy for a fair, healthy and environmentally friendly food system. European Commission, Brussels. https://eurlex.europa.eu/legal-content/EN/TXT/?qid=1590404602495\&uri=C ELEX\%3A52020DC0381 Accessed 20 January 2021.

Eurostat (2020) Eurostat statistics explained. Glossary: Carbon dioxide equivalent. https://ec.europa.eu/eurostat/statistics-explained/index.php/ Glossary:Carbon dioxide equivalent Accessed 20 January 2021.

FAO (2017) Food Agriculture Organization, FAOSTAT. http://faostat.fao.org/ site/567/DesktopDefault.aspx?PageID=567/ Accessed 20 January 2021.

Finnveden G, Hauschild MZ, Ekvall T, Guinée J, Heijungs R, Hellweg S, Koehler A, Pennington D, Suh S (2009) Recent developments in life cycle assessment. J Environ Manage 91:1-21. https://doi.org/10.1016/j.jenvman.2009.06.018

Fluck RC (1985) Energy sequestered in repairs and maintenance of agricultural machinery. T ASAE 28:738-744

Fluck RC (1992) Energy in farm production. Elsevier Science Publishers B.V, Amsterdam, The Netherlands

Genitsariotis M, Chlioumis G, Tsarouhas B, Tsatsarelis C, Sfakiotakis E (2000) Energy and nutrient inputs and outputs of a typical olive orchard in northern Greece. Act Hort 525:455-458

Genitsariotis M, Stougioti O, Tsarouhas B, Chlioumis G (1996) Alternative farming practices in integrated olive groves. Aristotle University of Thessaloniki, Greece (in Greek)

Ghasemi-Mobtaker H, Mostashari-Rad F, Saber Z, Chau KW, Nabavi-Pelesaraei A (2020) Application of photovoltaic system to modify energy use, environmental damages and cumulative exergy demand of two irrigation systems - a case study: barley production of Iran. Renew Energ 160:1316-1334. https://doi. org/10.1016/j.renene.2020.07.047

Gkisakis VD, Volakakis N, Kosmas E, Kabourakis EM (2020) Developing a decision support tool for evaluating the environmental performance of olive production in terms of energy use and greenhouse gas emissions. Sustain Prod Consumption 24:156-168. https://doi.org/10.1016/j.spc.2020.07.003

Huang J, Chen Y, Pan J, Liu W, Yang G, Xiao X, Zheng H, Tang W, Tang H, Zhou L (2019) Carbon footprint of different agricultural systems in China estimated by different evaluation metrics. J Clean Prod 225:939-948. https://doi.

org/10.1016/j.jclepro.2019.04.044 
Hülsbergen KJ, Feil B, Biermann S, Rathke GW, Kalk WD, Diepenbrock W (2001) A method of energy balancing in crop production and its application in a longterm fertilizer trial. Agric Ecosyst Environ 86: 303-321

IPCC (1997) Greenhouse gas inventory reference manual, three volumes, Intergovernmental Panel on Climate Change. IPCC Technical Support Unit, London

IPCC (2006) Software for national gas inventories, Intergovernmental Panel on Climate Change. http://ipcc2006.air.sk/ Accessed 20 January 2021.

IPCC (2014) Climate change 2014: mitigation of climate change. Contribution of Working Group III to the Fifth Assessment Report of the Intergovernmental Panel on Climate Change. Cambridge University Press, Cambridge, United Kingdom. http://report.mitigation2014.org/drafts/final-draft-postplenary/ ipcc_wg3_ar5_final-draft_postplenary_chapter11.pdf Accessed 20 January 2021.

ISO (2006a) Environmental management-life cycle assessment principles and framework ISO-Norm 14040:2006. International Organization for Standardization. European Committee for Standardization, Brussels, Belgium

ISO (2006b) Environmental management-life cycle Assessment requirements and guidelines ISO-Norm 14044:2006. International Organization for Standardization. European Committee for Standardization, Brussels, Belgium

ISO (2013) Carbon footprint of products-requirements and guidelines for quantification and communication. ISONorm 14067:2013. International Organization for Standardization. European Committee for Standardization, Brussels, Belgium. http://www.iso.org/iso/iso_catalogue/catalogue_tc/ catalogue_detail.htm?csnumber $=59521$ Accessed 20 January 2021.

Jarach M (1985) Sui valori di equivalenza per l'analysi e il bilancio energetici in agricoltura. Riv Ing Agrar 2:102-114

Kaab A, Sharifi M, Mobli H, Nabavi-Pelesaraei A, Chau KW (2019) Use of optimization techniques for energy use efficiency and environmental life cycle assessment modification in sugarcane production. Energy 181:1298-1320. https://doi.org/10.1016/j.energy.2019.06.002

Kaltsas AM (2005) Energy input-output for conventional and organic olives groves in Thasos island. Aristotle University of Thessaloniki, Greece, MSc thesis (in Greek)

Kaltsas AM, Mamolos AP, Tsatsarelis CA, Nanos GD, Kalburtji KL (2007) Energy budget in organic and conventional olive groves. Agr Ecosyst Environ 122:243251. https://doi.org/10.1016/j.agee.2007.01.017

Kavargiris SE, Mamolos AP, Tsatsarelis CA, Nikolaidou AE, Kalburtji KL (2009) Energy resources' utilization in organic and conventional vineyards: energy flow, greenhouse gas emissions and biofuel production. Biomass Bioenerg 33:1239-1250. https://doi.org/10.1016/j.biombioe.2009.05.006

Kehagias MC, Michos MC, Menexes GC, Mamolos AP, Tsatsarelis CA, Anagnostopoulos CD, Kalburtji KL (2015) Energy equilibrium and carbon dioxide, methane, and nitrous oxide-emissions in organic, integrated and 
conventional apple orchards related to Natura 2000 site. J Clean Prod 91:8995. https://doi.org/10.1016/j.jclepro.2014.12.007

Khoshnevisan B, Rafiee S, Omid M, Mousazadeh H (2013) Applying data envelopment analysis approach to improve energy efficiency and reduce GHG (greenhouse gas) emission of wheat production. Energy 58:588-593. https:// doi.org/10.1016/j.energy.2013.06.030

Küstermann B, Kainz M, Hülsbergen KJ (2008) Modelling carbon cycles and estimation of greenhouse gas emissions from organic and conventional farming systems. Renew. Agr Food Syst 23:1-16. https://doi.org/10.1017/ $\underline{\mathrm{S} 1742170507002062}$

Lazaroiu G, Mihaescu L, Negreanu G, Pana C, Pisa I, Cernat A, Ciupageanu DA (2018) Experimental investigations of innovative biomass energy harnessing solutions. Energies 11(12):3469. https://doi.org/10.3390/en11123469

Lichtfouse E (ed) (2011) Agroecology and strategies for climatic change: sustainable agricultural reviews 8. Springer, Berlin, Heidelberg

Litskas V, Chrysargyris A, Stavrinides M, Tzortzakis N (2019) Water-energy-food nexus: a case study on medicinal and aromatic plants. J Clean Prod 233:13341343. https://doi.org/10.1016/j.jclepro.2019.06.065

Litskas VD, Irakleous T, Tzortzakis N, Stavrinides MC (2017) Determining the carbon footprint of indigenous and introduced grape varieties through Life Cycle Assessment using the island of Cyprus as a case study. J Clean Prod 156:418-425. https://doi.org/10.1016/j.jclepro.2017.04.057

Litskas VD, Karaolis CS, Menexes GC, Mamolos AP, Koutsos TM, Kalburtji KL (2013) Variation of energy flow and greenhouse gas emissions in vineyards located in Natura 2000 sites. Ecol Indicat 27: 1-7. https://doi.org/10.1016/j. ecolind.2012.11.016

Litskas VD, Mamolos AP, Kalburtji KL, Tsatsarelis CA, Kiose-Kampasakali E (2011) Energy flow and greenhouse gas emissions in organic and conventional sweet cherry orchards located in or close to Natura 2000 sites. Biomass Bioenerg 35:1302-1310. https://doi.org/10.1016/j.biombioe.2010.12.023

Liu Y, Langer V, Høgh-Jensen H, Egelyng H (2010) Life cycle assessment of fossil energy use and greenhouse gas emissions in Chinese pear production. J Clean Prod 18:1423-1430. https://doi.org/10.1016/j.jclepro.2010.05.025

Lockeretz W (1980) Energy inputs for nitrogen, phosphorus and potash fertilizers. In: Pimentel D (ed) Handbook of energy utilization in agriculture. CRC Press, Boca Raton, FL, pp 15-21

Makhijani A, Poole A (1975) Energy and agriculture in the third world. Ballinger Publishing Company, Cambridge Mehta C, Patel R (1996) SPSS exact tests 7.0 for Windows. SPSS Inc., Chicago

Michos MC, Mamolos AP, Menexes GC, Tsatsarelis CA, Tsirakoglou VM, Kalburtji KL (2012) Energy inputs, outputs and greenhouse gas emissions in organic, integrated and conventional peach orchards. Ecol Indicat 13:22-28. https://doi. org/10.1016/j.ecolind.2011.05.002 
Michos MC, Menexes GC, Kalburtji KL, Tsatsarelis CA, Anagnostopoulos CD, Mamolos AP (2017) Could energy flow in agro-ecosystems be used as a "tool" for crop and farming system replacement? Ecol Indicat 73:247-253. https:// doi.org/10.1016/j.ecolind.2016.09.050

Michos MC, Menexes GC, Mamolos AP, Tsatsarelis CA, Anagnostopoulos CD, Tsaboula AD, Kalburtji KL (2018) Energy flow, carbon and water footprints in vineyards and orchards to determine environmentally favourable sites in accordance with Natura 2000 perspective. J Clean Prod 187:400-408. https:// doi.org/10.1016/j.jclepro.2018.03.251

Milà i Canals L, Burnip GM, Cowell SJ (2006) Evaluation of the environmental impacts of apple production using life cycle assessment (LCA): case study in New Zealand. Agric Ecosyst Environ 114: 226-238. https://doi.org/10.1016/j. agee.2005.10.023

Minagric (2007) Ministry of Agriculture. Restructuring prospects and growth of citrus sector. http://www.minagric.gr/images/stories/docs/ypoyrgeio/ dimosieyseis-Arthra/meleti gia Nea KAP/filadia fytikis/ESPERIDOEIDH.pdf Accessed 20 January 2021.

Mostashari-Rad F, Ghasemi-Mobtaker H, Taki M, Ghahderijani M, Kaab A, Chau K, Nabavi-Pelesaraei A (2021) Exergoenvironmental damages assessment of horticultural crops using ReCiPe2016 and cumulative exergy demand frameworks. J Clean Prod 278:123788. https://doi.org/10.1016/j. jclepro.2020.123788

Mostashari-Rad F, Nabavi-Pelesaraei A, Soheilifard F, Hosseini-Fashami F, Chau KW (2019) Energy optimization and greenhouse gas emissions mitigation for agricultural and horticultural systems in Northern Iran. Energy 186:115845. https://doi.org/10.1016/j.energy.2019.07.175

Mudahar MS, Hignett TP (1987) Energy requirements in the fertilizer sector. In: Helsel ZR (ed) Energy in plant nutrition and pest control. Elsevier, Amsterdam, The Netherlands, pp 25-61

Nabavi-Pelesaraei A, Amid S (2014) Reduction of greenhouse gas emissions of eggplant production by energy optimization using DEA approach. Elixir Energy Environ 69:23696-23701

Nabavi-Pelesaraei A, Abdi R, Rafiee S, Mobtaker HG (2014a) Optimization of energy required and greenhouse gas emissions analysis for orange producers using data envelopment analysis approach. J Clean Prod 65:311-317. https:// doi.org/10.1016/j.jclepro.2013.08.019

Nabavi-Pelesaraei A, Fatehi F, Mahmoudi A (2014b) Prediction of yield and economic indices for tangerine production using artificial neural networks based on energy consumption. Int J Agron Agr Res 4(5): 57-64. https://doi. org/10.6084/Mg.FIGSHARE.1603345

Nabavi-Pelesaraei A, Rafiee S, Hosseinzadeh-Bandbafha H, Shamshirband S (2016) Modeling energy consumption and greenhouse gas emissions for kiwifruit production using artificial neural networks. J Clean Prod 133:924931. https://doi.org/10.1016/j.jclepro.2016.05.188 
Navarro-Miró D, Iocola I, Persiani A, Blanco-Moreno JM, Kristensen HL, Hefner M, Tamm K, Bender I, Védie H, Willekens K, Diacono M, Montemurro F, Sans FX, Canali S (2019) Energy flows in European organic vegetable systems: effects of the introduction and management of agroecological service crops. Energy 188: 116o96. https://doi.org/10.1016/j.energy.2019.116096

Ozkan B, Akcaoz H, Karadeniz F (2004) Energy requirement and economic analysis of citrus production in Turkey. Energ Convers Manage 45:1821-1830. https://doi.org/10.1016/j.enconman.2003.10.002

Pandey D, Agrawal M (2014) Carbon footprint estimation in the agriculture sector. In: Muthu SS (ed) Assessment of carbon footprint in different industrial sectors, Vol. 1. Ecoproduction. Springer, Singapore, pp 25-47.

Pellegrini P, Fernández RJ (2018) Crop intensification, land use, and onfarm energy-use efficiency during the worldwide spread of the green revolution. P Natl Acad Sci USA 115(10):2335-2340. https://doi.org/10.1073/ pnas.1717072115

Pimentel D (1980) Handbook of energy utilization in agriculture. CRC Press, Boca Raton, FL

Pimentel D, Pimentel M (1996) Food, energy and society. University Press of Colorado.

Pimentel DL, Hurd E, Belloti AL, Forster MJ, Oka JN, Sholes OD, Whitman RJ (1973) Food production and the energy crisis. Science 182:443-449. https:// doi.org/10.1126/science.182.4111.443

Platis DP, Anagnostopoulos CD, Tsaboula AD, Menexes GC, Kalburtji KL, Mamolos AP (2019) Energy analysis, and carbon and water footprint for environmentally friendly farming practices in agroecosystems and agroforestry. Sustainability 11(6):1664. https://doi.org/10.3390/su11061664

Raheli H, Rezaei RM, Jadidi MR, Mobtaker HG (2017) A two-stage DEA model to evaluate sustainability and energy efficiency of tomato production. Inf Pro Agr 4:342-350. https://doi.org/10.1016/j.inpa.2017.02.004

Schader C, Grenz J, Meier MS, Stolze M (2014) Scope and precision of sustainability assessment approaches to food systems. Ecol Soc 19(3):42. https://doi.org/10.5751/ES-06866-190342

Strapatsa AV, Nanos GD, Tsatsarelis CA (2006) Energy flow for integrated apple production in Greece. Agric Ecosyst Environ 116:176-18o. https://doi. org/10.1016/j.agee.2006.02.003

Taxidis ET, Menexes GC, Mamolos AP, Tsatsarelis CA, Anagnostopoulos CD, Kalburtji KL (2015) Comparing organic and conventional olive groves relative to energy use and greenhouse gas emissions associated with the cultivation of two varieties. Appl Energ 149:117-124. https://doi.org/10.1016/j. apenergy.2015.03.128

Tilman D, Cassman KG, Matson PA, Naylor R, Polasky S (2002) Agricultural sustainability and intensive production practices. Nature 48:671-677

Tsatsarelis CA (1991) Energy requirements for cotton production in central Greece. J Agr Eng Res 50:239-246. https://doi.org/10.1016/ So021-8634(05)80017-4 
Tsatsarelis CA (1992) Energy flow in sugar-beet production in Greece. Appl Eng Agric ASAE 8:585-589

Tsatsarelis CA (1993) Energy inputs and outputs for soft winter wheat production in Greece. Agr Ecosyst Environ 43:109-118. https://doi. org/10.1016/0167-8809(93)90113-4

Tsatsarelis CA (2011) Agricultural tractors, 2nd edn. Giahoudi Giapouli press, Thessaloniki (in Greek)

Tsatsarelis CA, Koundouras DS (1994) Energetics of baled alfalfa hay production in northern Greece. Agr Ecosyst Environ 49:123-130. https://doi. org/10.1016/0167-8809(94)90002-7

Unakitan G, Aydın B (2018) A comparison of energy use efficiency and economic analysis of wheat and sunflower production in Turkey: a case study in Thrace Region. Energy 149:279-285. https://doi.org/10.1016/j.energy.2018.02.033

Villanueva-Rey P, Vázquez-Rowe I, Moreira MT, Feijoo G (2014) Comparative life cycle assessment in the wine sector: biodynamic vs. conventional viticulture activities in NW Spain. J Clean Prod 65: 330-341. https://doi.org/10.1016/j. jclepro.2013.08.026

Zafiriou P, Mamolos AP, Menexes GC, Siomos AS, Tsatsarelis CA, Kalburtji KL (2012) Analysis of energy flow and greenhouse gas emissions in organic, integrated and conventional cultivation of white asparagus by PCA and HCA: cases in Greece. J Clean Prod 29:20-27. https://doi.org/10.1016/j. jclepro.2012.01.040 